Prepared in cooperation with Federal Emergency Management Agency

\title{
Flood Magnitude and Frequency of the Delaware River in New Jersey, New York, and Pennsylvania
}

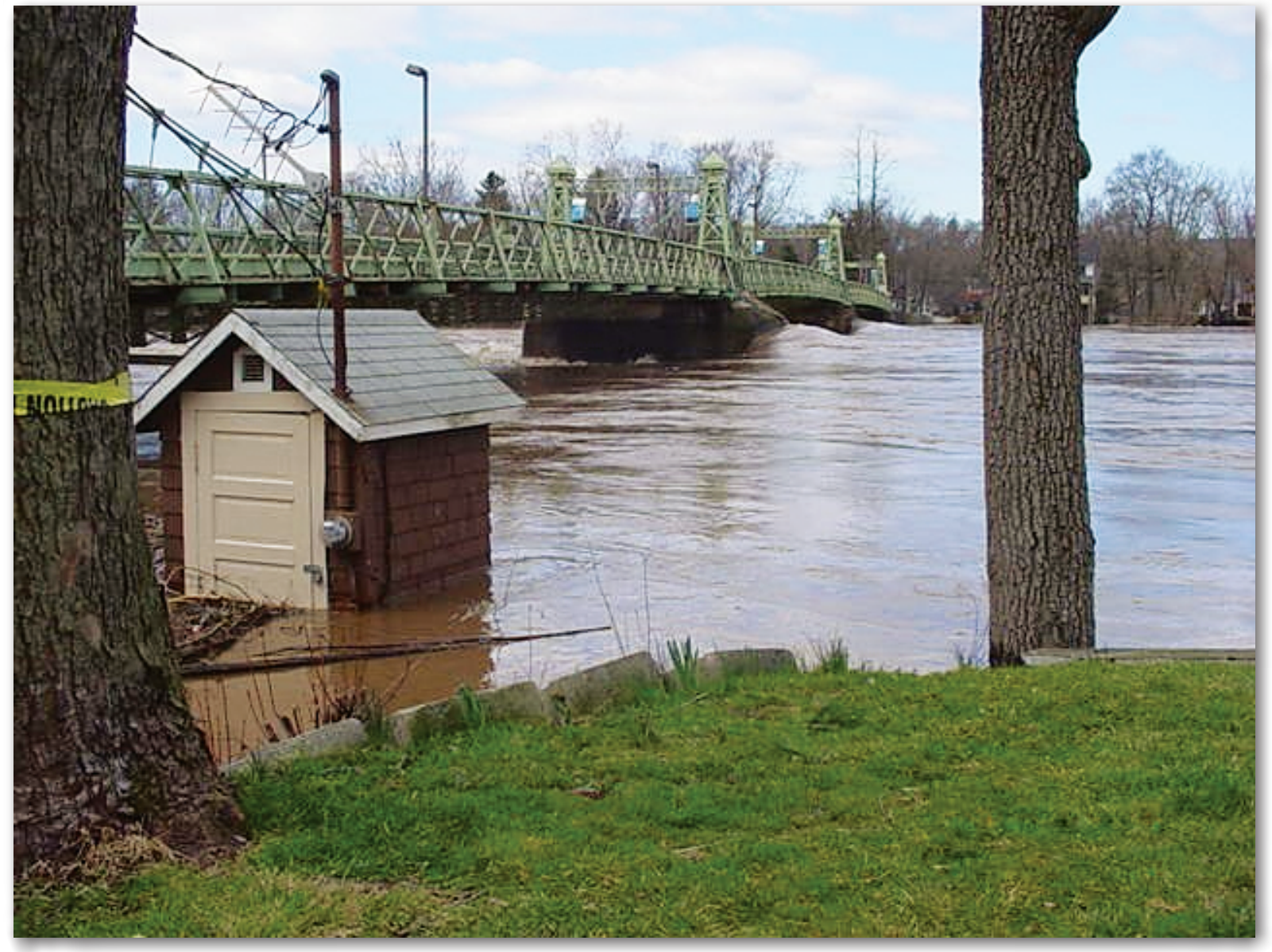

Open-File Report 2008-1203 
Cover. USGS stream-gaging station 01457500, Delaware River at Riegelsville, New Jersey, during the April 4, 2005, flood. Photograph taken by Amy McHugh, USGS. 


\section{Flood Magnitude and Frequency of the Delaware River in New Jersey, New York, and Pennsylvania}

By Robert D. Schopp and Gary D. Firda

Prepared in cooperation with Federal Emergency Management Agency

Open-File Report 2008-1203 


\section{U.S. Department of the Interior DIRK KEMPTHORNE, Secretary}

\section{U.S. Geological Survey \\ Mark D. Myers, Director}

\section{U.S. Geological Survey, Reston, Virginia: 2008}

For product and ordering information:

World Wide Web: http://www.usgs.gov/pubprod

Telephone: 1-888-ASK-USGS

For more information on the USGS--the Federal source for science about the Earth, its natural and living resources, natural hazards, and the environment:

World Wide Web: http://www.usgs.gov

Telephone: 1-888-ASK-USGS

Any use of trade, product, or firm names is for descriptive purposes only and does not imply endorsement by the U.S. Government.

Although this report is in the public domain, permission must be secured from the individual copyright owners to reproduce any copyrighted materials contained within this report.

Suggested citation:

Schopp, R.D., and Firda, G.D., 2008, Flood magnitude and frequency of the Delaware River in New Jersey, New York, and Pennsylvania: U.S. Geological Survey Open-File Report 2008-1203, 7 p. 


\section{Contents}

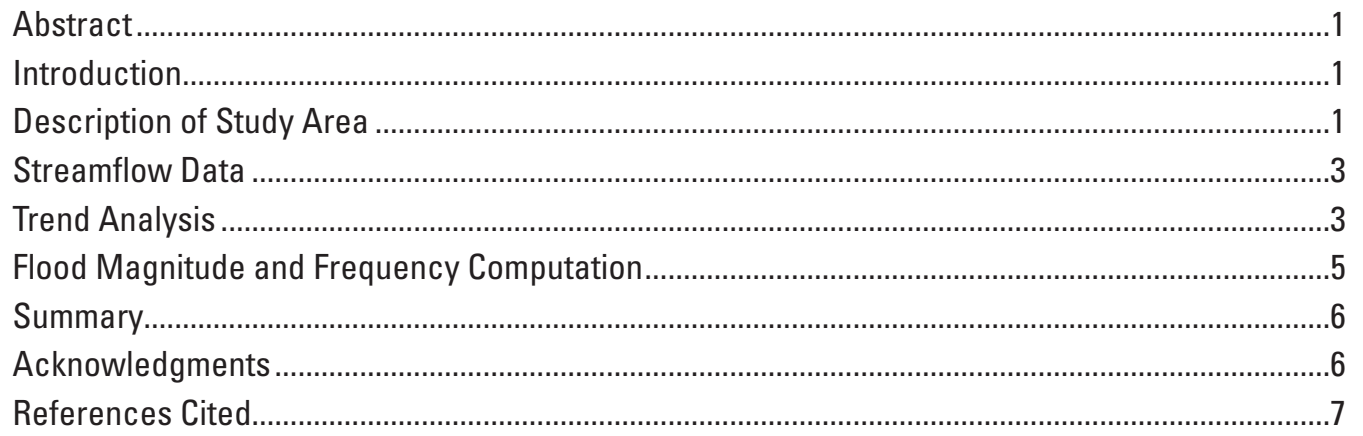

\section{Figures}

1. Map showing location of U.S. Geological Survey streamflow-gaging stations on the

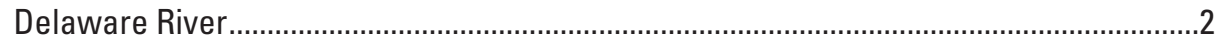

2. Plot showing annual flood peaks recorded on the Delaware River at Trenton, N.J., water years 1898-2006

\section{Tables}

1. Streamflow-gaging stations on the main stem Delaware River.

2. Change in estimated forest cover for selected locations along the Delaware River, 1894 to 1992.

.5

3. Flood magnitude and frequency for streamflow-gaging stations on the main stem

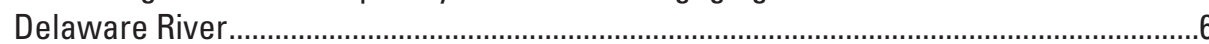




\section{Conversion Factors}

\begin{tabular}{lcl}
\hline \multicolumn{1}{c}{ Multiply } & \multicolumn{1}{c}{ By } & \multicolumn{1}{c}{ To obtain } \\
\hline \multicolumn{2}{c}{ Length } & \\
inch (in.) & 25.4 & millimeter $(\mathrm{mm})$ \\
inch (in.) & 0.0254 & meter $(\mathrm{m})$ \\
\hline & \multicolumn{1}{c}{ Area } & \\
\hline square mile $\left(\mathrm{mi}^{2}\right)$ & 259.0 & hectare $(\mathrm{ha})$ \\
square mile $\left(\mathrm{mi}^{2}\right)$ & 2.590 & square kilometer $\left(\mathrm{km}^{2}\right)$ \\
\hline & Flow rate & \\
cubic foot per second $(\mathrm{ft} / \mathrm{s})$ & 0.02832 & cubic meter per second $\left(\mathrm{m}^{3} / \mathrm{s}\right)$ \\
\hline
\end{tabular}




\title{
Flood Magnitude and Frequency of the Delaware River in New Jersey, New York, and Pennsylvania
}

\author{
By Robert D. Schopp and Gary D. Firda
}

\section{Abstract}

From September 2004 to June 2006, the Delaware River in New Jersey, New York, and Pennsylvania experienced three major floods that caused extensive damage. The Federal Emergency Management Agency (FEMA) needed updated information on the flood magnitude and frequency for the eight active streamflow-gaging stations along the main stem Delaware River in New Jersey, New York, and Pennsylvania that included the three recent floods in order to update its flood insurance studies. Therefore, the U.S. Geological Survey (USGS) computed updated flood magnitude and frequency values following the guidelines published by the Interagency Advisory Committee on Water Data in its Bulletin 17B. The updated flood-frequency values indicate that the recurrence interval of the September 2004 flood ranged from 20 to 35 years, the recurrence interval of the April 2005 flood ranged from 40 to 70 years, and the recurrence interval of the June 2006 flood ranged from 70 to greater than 100 years. Examination of trends in flood discharges indicate no statistically significant trends in peak flows during the period of record for any of the eight streamflow-gaging stations.

\section{Introduction}

During the 22-month period from September 2004 to June 2006, the Delaware River experienced three major floods that caused extensive damage. The Federal Emergency Management Agency (FEMA) needed updated information on flood magnitude and frequency for the eight active streamflow-gaging stations along the main stem Delaware River in New Jersey, New York, and Pennsylvania that included the three recent floods in order to update its floodinsurance studies for the Delaware. Therefore, the U.S. Geological Survey (USGS) computed new flood magnitude and frequency values for the eight stations, and examined trends in flood discharges. Possible reasons for the occurrence of the three high-magnitude floods in a 22-month period were also examined.
This report presents the methodology and resulting flood magnitude and frequency values, including 2-, 5-, 10-, 25-, 50-, 100-, and 500-year recurrence intervals, for eight active streamflow-gaging stations (stations) on the Delaware River and presents the results of the trend analysis.

The U.S. Army Corps of Engineers (the Corps) and FEMA flood-insurance studies have been using a set of flood magnitude and frequency values that were initially computed in 1962 (U.S. Army Corps of Engineers, 1962) and were last updated in 1984 (U.S. Army Corps of Engineers, 1984). The effects of reservoir storage were removed from the observed flood peaks using a HEC-1 computer program (U.S. Army, Corps of Engineers, Hydrologic Engineering Center, 1973) with the assumption that the reservoirs were full at the beginning of the floods. Both analyses (1962 and 1984) were developed using a mixed population analysis in which non-hurricane floods and floods caused by tropical storms and hurricanes are analyzed separately. The results of the two analyses were then combined, and the combined results were readjusted from unregulated conditions to the current regulated conditions. The flood-frequency values were then graphically combined with USGS computations using observed flood-peak discharges.

\section{Description of Study Area}

The study area is the main stem of the Delaware River in the States of New Jersey, New York, and Pennsylvania. The Delaware River has its headwaters in New York State. The river has two headwater streams, the East Branch and the West Branch; both rise in the Catskill Mountains. The two branches join at Hancock, N.Y. From there the river flows downstream to Trenton, N.J., which is at the head of tide. The eight active and two inactive streamflow-gaging stations include stations on the main stem downstream to and including Trenton, N.J. Stations farther downstream on the main stem are tidally affected and, therefore, are outside the study area. The drainage area of the station that is farthest downstream is $6,780 \mathrm{mi}^{2}$ and contains nine major reservoirs (fig. 1). 


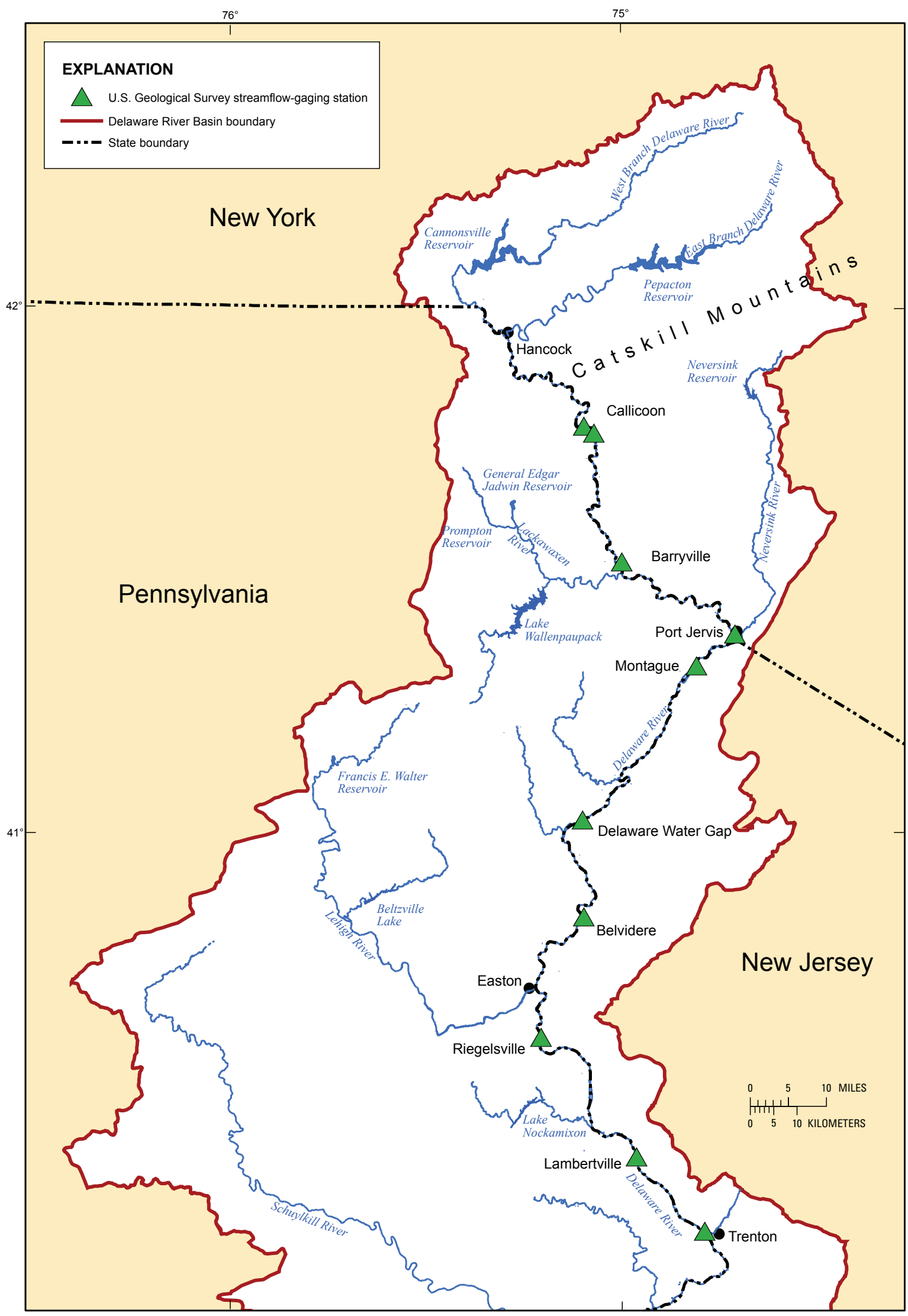

Figure 1. Location of U.S. Geological Survey streamflow-gaging stations on the Delaware River. 


\section{Streamflow Data}

Information on flooding along the Delaware River dates back to a major flood that occurred in 1692. Reliable sources of historic flood-peak stages and discharges are publications by Mangan (1942) and Thomas (1964). These data are available on the World Wide Web at the USGS Peak Flow File web site (http://nwis.waterdata.usgs.gov/usa/nwis/peak/). Table 1 summarizes the peak-flow data available for stations on the main stem Delaware River.

Two locations were utilized for gaging in the vicinity of Callicoon, N.Y. (see table 1). The peak-flow records collected at the gage 01427410 Delaware River near Callicoon, N.Y. (period of record water years 1968-75), were adjusted to the present gage site 01427510, Delaware River at Callicoon, N.Y., using a simple drainage-area ratio.

Two locations were utilized for gaging in the vicinity of Trenton, N.J. (see table 1). The peak-flow records collected at the gage 01462000, Delaware River at Lambertville, N.J. (period of record water years 1898-1907, except water year 1904), were adjusted to the present gage site 01463500 , Delaware River at Trenton, N.J., using a simple drainage-area ratio. Water years run from October 1 to September 30 and are designated by the ending year.

\section{Trend Analysis}

A trend analysis was performed on annual peak-flow series for the eight long-term main stem gages, including the two gages for which records were combined, to determine whether an overall trend was present in the peak flows during the period of record. The trend test used was the Kendall Tau test in the USGS computer program SWSTAT (Lumb and others, 1990). None of the gage records showed a statistically significant trend at the 95-percent confidence level. Figure 2 shows a plot of the annual flood peaks versus water year for the Delaware River at Trenton, N.J.

Much public discussion has taken place regarding possible reasons for the occurrence of three high flood peaks in only a 22-month period. Although, the Kendall Tau test did not indicate a statistically significant trend in the flooding, possible causes of a change in flood magnitude and frequency were examined. Possible reasons for a change in the flood magnitude and frequency include:

1. increased impervious cover due to development,

2. changes in the magnitude of flood peaks due to construction of reservoirs in the basin,

3. changes in forest cover in the basin, and

4. changes due to global climate warming and longterm precipitation cycles.

Increases in man-made imperious cover in the basin would be expected to increase peak discharges. Increases would be greater for low-recurrence interval floods, such as the 2- and 5-year floods, than for high-recurrence-interval floods. After a few inches of rain have fallen, the soils tend to become saturated and act as impervious cover, and do not retain much of the subsequent rainfall; therefore, increases in flow at the 100-year recurrence interval likely would be fairly minor. Preliminary computations using population density (which was correlated with the percentage of the basin with man-made impervious cover) (Stankowski, 1974) in the Delaware River Basin upstream from Trenton and Stankowski's (1974) equation for estimating the 100-year flood indicate that peak discharge would be increased less than 10 percent due to population growth between 1900 and 2000 .

Table 1. Streamflow-gaging stations on the main stem Delaware River.

\begin{tabular}{clcc}
$\begin{array}{c}{\left[\mathrm{mi}^{2}, \text { square miles }\right]} \\
\begin{array}{c}\text { USGS station } \\
\text { number }\end{array}\end{array}$ & \multicolumn{1}{c}{ Station name } & Drainage area, in mi ${ }^{2}$ & Period of record, in water years $^{1}$ \\
\hline 01427410 & Delaware River near Callicoon, N.Y. ${ }^{2}$ & 1,708 & $1968-1975$ \\
01427510 & Delaware River at Callicoon, N.Y. & 1,820 & $1976-2006$ \\
01428500 & Delaware River above Lackawaxen River near Barryville, N.Y. & 2,020 & $1941-2006$ \\
01434000 & Delaware River at Port Jervis, N.Y. & 3,070 & $1904-2006$ \\
01438500 & Delaware River at Montague, N.J. & 3,480 & $1904,1936-2006$ \\
01440200 & Delaware River near Delaware Water Gap, Pa. & 3,850 & $1955,1964-1996,2002-2006$ \\
01446500 & Delaware River at Belvidere, N.J. & 4,535 & $1904,1923-2006$ \\
01457500 & Delaware River at Riegelsville, N.J. & 6,328 & $1841,1904,1907-2006$ \\
01462000 & Delaware River at Lambertville, N.J. ${ }^{3}$ & 6,680 & $1898-1907$ \\
01463500 & Delaware River at Trenton, N.J. ${ }^{3}$ & 6,780 & $1904,1913-2006$
\end{tabular}

${ }^{1}$ Water years run from October 1 to September 30 and are designated by the ending year.

${ }^{2}$ Records for stations 01427410 and 01427510 were combined for the analysis for 01427510 .

${ }^{3}$ Records for stations 01462000 and 01463500 were combined for the analysis for 01463500 . 


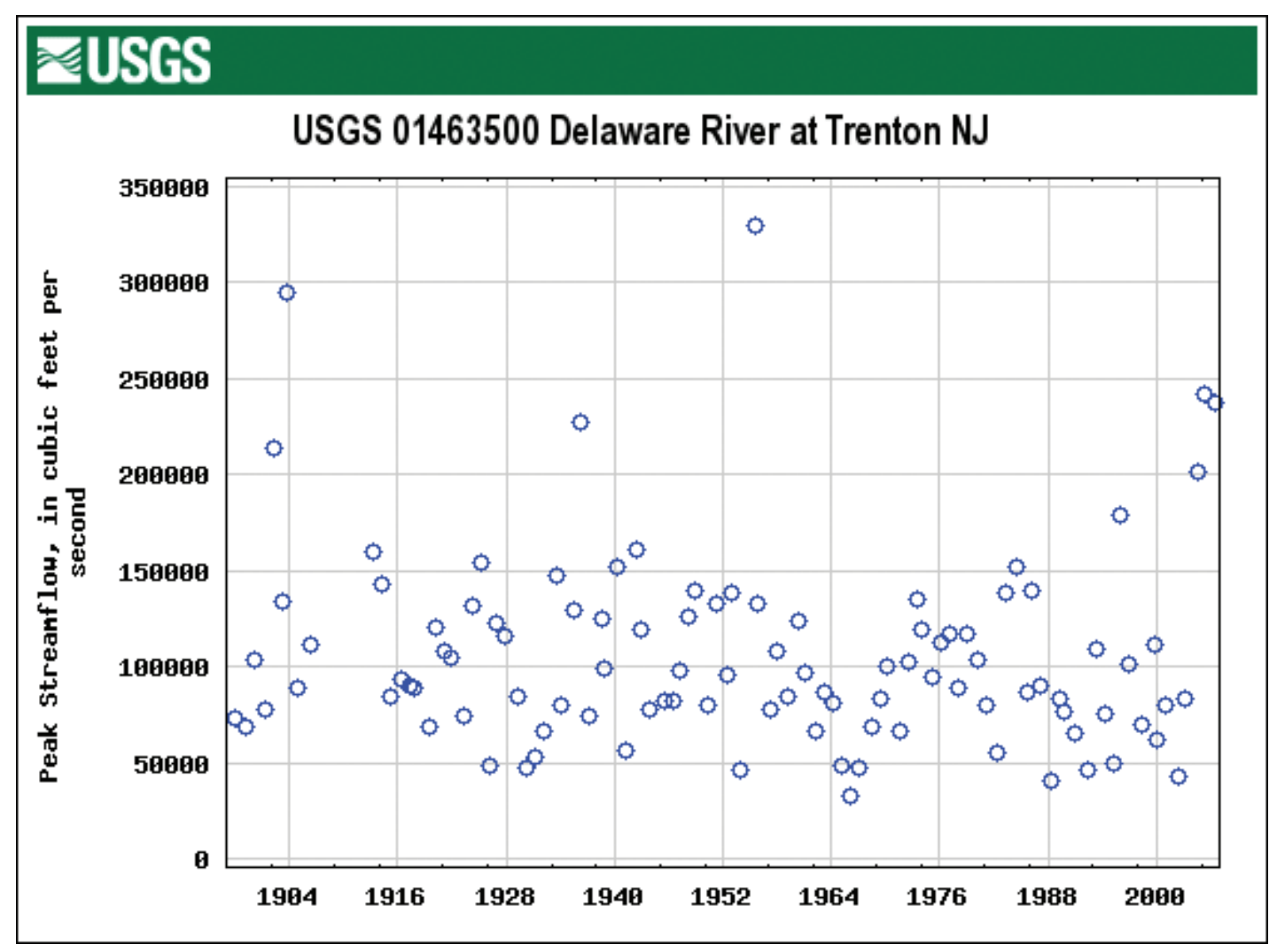

Figure 2. Plot showing annual flood peaks recorded on the Delaware River at Trenton, N.J., water years 1898-2006. Accessed July 6, 2007, at http://nwis.waterdata.usgs.gov/nj/nwis/peak/?site_no=01463500\&agency_cd $=U S G S$.

Several major reservoirs have been built in the Delaware River Basin upstream from Trenton in the last 100 years (fig. 1):

- Pepacton Reservoir, New York City water-supply reservoir on East Branch Delaware River, completed 1954;

- Cannonsville Reservoir, New York City water-supply reservoir on West Branch Delaware River, completed 1963;

- Prompton Reservoir, on Lackawaxen River, U.S. Army Corps of Engineers flood-control dam, completed 1960;

- General Edgar Jadwin Reservoir, U.S. Army Corps of Engineers flood-control dam on Dyberry Creek, completed 1959;

- Lake Wallenpaupack, Pennsylvania Power and Light Company hydropower facility on Wallenpaupack Creek, completed 1925;
- Neversink Reservoir, New York City water-supply reservoir on Neversink River, completed 1953;

- Francis E. Walter Reservoir, U.S. Army Corps of Engineers flood-control reservoir on Lehigh River, completed 1961;

- Beltzville Lake, U.S. Army Corps of Engineers floodcontrol reservoir on Pohopoco Creek, completed 1971; and

- Lake Nockamixon, Pennsylvania Department of Environmental Protection water-supply and flood-control reservoir on Tohickon Creek, completed 1973.

In almost all cases, whether water levels are at spillway elevation or drawdown, reservoirs will attenuate peak discharges because the surface area available for storage is larger than that available in the natural floodplain before dam construction. This might not be true if there are large gates in the dam that release large amounts of water. Some of the reservoirs listed above were designed for water supply and do not have gates to release large quantities of water. 
Forest cover in the basin was considered as a factor in the magnitude of flooding. Table 2 shows changes in estimates of percentage forest cover at three locations along the main stem Delaware River from 1894 (Vermeule, 1894) to 1992 (U.S. Geological Survey, 1992). The methodologies used in the two studies differ greatly, but the general conclusions are believed to be valid. At all three locations, the percent forest cover has increased substantially. Much of the basin was clear cut for timber in the late 1800 s, or was cleared for farming. Increases in percent forest cover typically cause decreases in flood-peak discharges.

Global climate warming is expected to raise air temperatures with time. The effects of these higher air temperatures on rainfall and flooding in the Delaware River Basin are not clear. Various general circulation models yield conflicting projections (Ayers and others, 1994). There are various cyclical patterns in rainfall, with some cycles lasting 1 or 2 months, 30 years, 500, or tens of thousands of years. Studies of streamflow patterns performed by Lins (2005) indicate a shift to a wetter period beginning in 1940 and an abrupt shift to an even wetter period in the northeastern United States about 1970.

Examination of the flood-peak stage data recorded at Easton, Pa., (http://nwis.waterdata.usgs.gov/usa/nwis/peak/) shows that over the last 300 years, six of the seven highest flood stages occurred after 1900, and only one occurred before that time, in 1841. The timing of these floods could be attributable to climate cycles greater than 100 years. In this study it was decided to use only flood information collected after 1898, when the first USGS gaging station was established at Lambertville, N.J., for this study. Data collected before 1898 primarily consisted of high-water marks from local residents, newspapers, and historic accounts.

Table 2. Change in estimated forest cover for selected locations along the Delaware River, 1894 to 1992.

[All values in percent]

\begin{tabular}{lccc} 
Location & 11894 & ${ }^{21992}$ & Change \\
\hline $\begin{array}{l}\text { Delaware River above Delaware } \\
\text { Water Gap, Pa. }\end{array}$ & 59 & ${ }^{3} 82$ & +39 \\
$\begin{array}{l}\text { Delaware River above Easton, Pa. } \\
\text { Lehigh River near mouth, Pa. }\end{array}$ & 45 & 81 & +47 \\
$\begin{array}{l}\text { Delaware River above Trenton, } \\
\text { N.J. }\end{array}$ & 51 & 75 & +34 \\
\hline $\begin{array}{l}{ }^{1} \text { C.C. Vermeule (1894, p. 231). } \\
{ }^{2} \text { U.S. Geological Survey (1992). }\end{array}$ & & & \\
${ }^{3}$ Interpolated value.
\end{tabular}

\section{Flood Magnitude and Frequency Computation}

A flood-frequency analysis was conducted on peak-flow data using the computer program PeakFQ (Flynn and others, 2006). The station skew was used for all gages rather than the WRC-weighted skew (Interagency Advisory Committee on Water Data, Hydrology Subcommittee,1982) because the drainage areas were large enough to represent multiple physiographic provinces and most of the gage records were fairly long (greater than 50 years). Historic adjustments were applied back to 1898 for Trenton and to the 1904 water year for the other stations. The base discharge for the historic adjustment was set at the 1955 flood-peak discharge.

The Callicoon (01427510) flood frequency analysis was adjusted using the two-station comparison procedure described in Appendix 7 of Bulletin 17B (Interagency Advisory Committee on Water Data, Hydrology Subcommittee, 1982). The Barryville gage (01428500) was used as the long-term record in this comparison.

The Montague (01438500) flood-frequency analysis was adjusted using the two-station comparison procedure described in Appendix 7 of Bulletin 17B (Interagency Advisory Committee on Water Data, Hydrology Subcommittee, 1982). The Port Jervis gage (01434000) was used as the long-term record in this comparison.

The Delaware Water Gap (01440200) flood-frequency analysis was adjusted using the two-station comparison procedure described in Appendix 7 of Bulletin 17B (Interagency Advisory Committee on Water Data, Hydrology Subcommittee, 1982). The Belvidere gage (01446500) was used as the long-term record in this comparison.

The U.S. Army Corps of Engineers (the Corps), Philadelphia District, performed a similar analysis following the procedures used in the last update of flood magnitudes and frequencies developed for FEMA flood-insurance studies on the main stem of the Delaware River. The major change in the analysis made by the Corps was to eliminate the mixed population analysis that had previously been used to analyze hurricane and non-hurricane flooding separately and then combine the two analyses. This change was made because of a lack of adequate data.

The analysis performed by the Corps involved using a HEC-1 computer program (U.S. Army Corps of Engineers, Hydrologic Engineering Center, 1973) to remove the affects of reservoir attenuation on the observed flood peaks. The assumption was made that the major reservoirs in the basin were full at the beginning of a storm. The attenuating effects of the reservoirs were then computed and used to adjust downstream observed peak. The dates that the various reservoirs were completed were taken into account.

The Corps then performed a log-Pearson Type III analysis of the unregulated peaks using most of the same assumptions used by the USGS. A power equation was developed to relate 
regulated to unregulated peaks at each gage. These power equations were then applied to the flood-frequency values developed for the unregulated peaks. The result was a floodfrequency curve for the degree of regulation that existed in 2006.

The USGS- and Corps-developed flood-frequency values were compared; most results were within 5 percent of each other values (table 3 ). The Delaware River Coordinating Committee, which includes representatives of the USGS, the Corps, FEMA, FEMA contractors, the Delaware River Basin Commission, the New Jersey Department of Environmental Protection, and the New Jersey Highlands Council, agreed to adopt the proposed flood-frequency values developed by USGS for use in ongoing FEMA flood insurance studies and U.S. Army Corps of Engineers flood studies.

Included with the flood-magnitude and -frequency results presented in table 3 is the New Jersey Flood Hazard Area Flood (NJFHAF), which is equal to 125 percent of the updated 100 -year flood magnitude. The NJFHAF is used by the New Jersey Department of Environmental Protection to apply their flood plain management regulations.

These updated flood-frequency values indicate that the recurrence interval of the September 2004 flood ranged from 20 to 35 years, the recurrence interval of the April 2005 flood ranged from 40 to 70 years, and the recurrence interval of the June 2006 flood ranged from 70 years in the New Jersey portions of the river to greater than 100 years in the Callicoon and Barryville portions of the river.

\section{Summary}

From September 2004 to June 2006, the Delaware River in New Jersey, New York, and Pennsylvania experienced three major floods that caused extensive damage. The U.S. Geological Survey (USGS) updated the flood-magnitude and -frequency values for the eight streamflow-gaging stations along the main stem Delaware River in New Jersey, New York, and Pennsylvania for use in (FEMA) flood-insurance studies and U.S. Army Corps of Engineers flood-control studies. Results of an analysis of trends in flood discharge indicated no statistically significant trend in peak flows during the period of record for any of the eight stations. The updated flood-frequency values indicate that the recurrence interval of the September 2004 flood ranged from 20 to 35 years, the recurrence interval of the April 2005 flood ranged from 40 to 70 years, and the recurrence interval of the June 2006 flood ranged from 70 to greater than 100 years.

\section{Acknowledgments}

The authors gratefully acknowledge the flood-frequency analysis and technical coordination provided by Robert A, Lowinski and Glendon T. Stevens of the U.S. Army Corps of Engineers, Philadelphia District. We also acknowledge Paul Weberg, Mary Colvin, and Jon Janowicz of the Federal Emergency Management Agency (Regions II, II, and III, respectively) for their input and counsel.

Table 3. Flood magnitude and frequency for streamflow-gaging stations on the main stem Delaware River

[USGS, U.S. Geological Survey; station locations shown in figure 1; ---, not determined; values are discharge, in cubic feet per second]

\begin{tabular}{|c|c|c|c|c|c|c|c|c|c|}
\hline $\begin{array}{c}\text { USGS } \\
\text { station } \\
\text { number }\end{array}$ & Station Name & \multicolumn{8}{|c|}{ Recurrence interval } \\
\hline 01428500 & $\begin{array}{l}\text { Delaware River above Lackawaxen } \\
\text { River near Barryville, N.Y. }\end{array}$ & 44,100 & 67,100 & 83,600 & 106,000 & 124,000 & 142,000 & --- & 188,000 \\
\hline 01438500 & Delaware River at Montague, N.J. & 65,200 & 101,000 & 127,000 & 164,000 & 194,000 & 226,000 & 282,000 & 308,000 \\
\hline 01440200 & $\begin{array}{l}\text { Delaware River near Delaware } \\
\text { Water Gap, Pa. }\end{array}$ & 71,800 & 110,000 & 139,000 & 178,000 & 210,000 & 244,000 & 305,000 & 332,000 \\
\hline 01463500 & Delaware River at Trenton, N.J. & 94,900 & 138,000 & 169,000 & 211,000 & 245,000 & 280,000 & 350,000 & 372,000 \\
\hline
\end{tabular}

${ }^{1}$ New Jersey Flood Hazard Area Flood, equal to 125 percent of the 100-year flood discharge 


\section{References Cited}

Ayres, M.A., Wolock, D.M., McCabe, G.J., Hay, L.E., and Tasker, G.D., 1994, Sensitivity of water resources in the Delaware River Basin to climate variability and change: U.S. Geological Survey Water-Supply Paper 2422, 42 p.

Flynn, K.M., Kirby, W.H., and Hummel, P.R., 2006, User's manual for program PeakFQ annual flood-frequency analysis using Bulletin 17B guidelines: U.S. Geological Survey Techniques and Methods, book 4, chap. B4, 42 p., 4 app.

Interagency Advisory Committee on Water Data, Hydrology Subcommittee, 1982, Guidelines for determining flood flow frequency: Bulletin 17B of the Hydrology Subcommittee, 28 p., 14 app.

Lins, H.F., 2005, Streamflow trends in the United States... from the National Streamflow Information Program: U.S. Geological Survey Fact Sheet 2005-3017, 4 p.

Lumb, A.M., Kittle, J.L., Jr., and Flynn, K.M., 1990, Users manual for ANNIE, a computer program for interactive hydrologic analyses and data management: U.S. Geological Survey Water-Resources Investigations Report 89-4080, $236 \mathrm{p}$.

Mangan, J.W., 1942, The floods of May 1942 in the Delaware and Lackawanna River Basins: Commonwealth of Pennsylvania, Department of Forests and Waters, 29 p.

Stankowski, S.J., 1974, Magnitude and frequency of floods in New Jersey with effects of urbanization: New Jersey Department of Environmental Protection, Division of Water Resources, Special Report 38, 46 p.
Thomas, D.M., 1964, Flood magnitude and frequency: New Jersey Department of Conservation and Economic Development, Division of Water Policy and Supply, Water Resources Circular 13, 145 p.

U.S. Army Corps of Engineers, 1962, Delaware River basin, New York, New Jersey, Pennsylvania, and Delaware: letter from the Secretary of the Army transmitting a letter from the Chief of Engineers, Department of the Army, dated April 2, 1962, submitting a report, together with accompanying papers and illustrations, on a review of the Delaware River and tributaries, Appendix M. Hydrology: House Document 522.

U.S. Army Corps of Engineers, Hydrologic Engineering Center, 1973, HEC-1 Flood Hydrograph Package, Users Manual: U.S. Army, Corps of Engineers, Hydrologic Engineering Center, 25 p., 6 app.

U.S. Army Corps of Engineers, 1984, Delaware River Basin Study, Survey Report, Main Report: 82 p., 4 appendices.

U.S. Geological Survey, 1992, National Land Cover Characterization, accessed December 17, 1997, at http://landcover. usgs.gov/natllandcover.php .

Vermeule, C.C., 1894, Report on water-supply, water power, the flow of streams and attendant phenomena: Geological Survey of New Jersey, Volume III of the Final Report of the State Geologist: Trenton, N.J., 351 p., 2 app. 

For additional information, write to:

Director

U.S. Geological Survey

New Jersey Water Science Center

810 Bear Tavern Rd., Suite 206

West Trenton, NJ 08628

or visit our Web site at:

http://nj.usgs.gov/ 
